\title{
Biochemical analysis of Cassia fistula aqueous extract and phytochemically synthesized gold nanoparticles as hypoglycemic treatment for diabetes mellitus
}

\author{
This article was published in the following Dove Press journal: \\ International Journal of Nanomedicine \\ 6 March 2012 \\ Number of times this article has been viewed
}

\section{P Daisy \\ K Saipriya}

Postgraduate and Research

Department of Biotechnology and

Bioinformatics, Holy Cross College,

Teppakulam, Trichy, Tamil Nadu, India

\begin{abstract}
Cassia fistula stem bark was used for the preparation of aqueous extract and synthesis of gold nanoparticles to evaluate the hypoglycemic effects of the plant. The synthesized gold nanoparticles were characterized by ultraviolet-visible spectroscopy for their absorbance pattern, Fourier transform infrared spectroscopy to identify possible functional groups, and scanning electron microscopy to determine the size of the nanoparticles. The present investigation reports the efficacy of the gold nanoparticles as promising in the treatment of hyperglycemia. Body weight, serum glucose concentrations, liver function tests, kidney function tests, and lipid profile were analyzed. A significantly larger decrease in serum biochemistry parameters and an increase in body weight, total protein levels, and high-density lipoprotein were observed in rats with streptozotocin-induced diabetes treated with gold nanoparticles than in the ones treated with the aqueous extract. The results of this study confirm that $C$. fistula gold nanoparticles have promising antidiabetic properties.
\end{abstract}

Keywords: diabetes mellitus, Cassia fistula, aqueous, gold nanoparticles, biochemical analysis

\section{Introduction}

Diabetes mellitus is a chronic metabolic disorder ${ }^{1}$ characterized by loss of glucose homeostasis caused by defects in insulin secretion and action, resulting in impaired glucose metabolism. ${ }^{2}$ Epidemiological studies and clinical trials strongly support the notion of hyperglycemia as the main cause of coronary heart disease, cerebrovascular disease, renal failure, limb amputation, neurological complications, premature death, and lipid abnormalities in diabetics. Diabetes mellitus has reached epidemic proportions among the challenging unresolved health problems of the 21 st century. The number of people suffering from the disease worldwide is increasing at an alarming rate, with a projected 366 million people likely to be diabetic by the year 2030 compared with the estimate of 191 million people in $2000 .{ }^{3}$ By convention, diabetes has been classified as type 1 (insulin-dependent) or type 2 (non-insulin-dependent). At present, controlling blood sugar levels by dietary modification, physical exercise, insulin therapy, and oral medications is advised. ${ }^{4}$ However, several hypoglycemic agents used for the treatment of diabetes are reported to have adverse effects, including liver problems, lactic acidosis, and diarrhea. ${ }^{5}$ Thus, use of these drugs may be limited depending on their pharmacokinetic properties, secondary failure rates, and side effects. ${ }^{6,7}$ The pathogenesis of diabetes mellitus and the possibility of its management with existing 
therapeutic agents without any side effects has been the subject of great interest in recent years. ${ }^{8}$

Researchers in the field of nanotechnology are gaining new insights into its versatile applications in the treatment of various diseases, including diabetes mellitus. Nanotechnology is an attractive area of research related to production of nanoparticles of variable size, shape, and chemical composition, with controlled dispersity, as well as their possible benefits in clinical medicine. ${ }^{9}$ The rapid development of nanotechnology worldwide has been accompanied by massive generation and widespread use of engineered nanomaterials. Biosynthesis of nanoparticles, as a representative intersection of nanotechnology and biotechnology, has been the focus of increasing attention due to the growing need to develop environmentally friendly technologies for materials synthesis. ${ }^{10}$ To date, nanoparticles have been extensively used in various applications, including drug discovery ${ }^{11}$ and tissue engineering. ${ }^{12}$ Research into the preparation and biological applicability of noble metal nanoparticles with a nearly monodispersed size distribution and arbitrarily variable size and geometry has attracted considerable research interest. ${ }^{13}$ Gold nanoparticles have a growing role in medical biotechnology. ${ }^{14}$ Production of nanoparticles can be achieved mainly through chemical, physical, and biological methods. Biological methods for nanoparticle synthesis using plants or plant extracts have been suggested as possible ecofriendly alternatives to chemical and physical methods. ${ }^{15}$

Since time immemorial, many medicinal plants have been used as dietary adjuncts and in the treatment of numerous diseases without proper knowledge of their function. Although phytotherapy continues to be used in a number of countries, few plants have undergone scientific or medical scrutiny. ${ }^{16}$ Phytochemically mediated synthesis of gold nanoparticles marks a potential advance in the drug discovery era. A range of medicinal plants and plant extracts has been used for biological synthesis of gold nanoparticles. Singh et $\mathrm{al}^{17}$ reported a green biogenic approach for the synthesis of gold and silver nanoparticles using aqueous leaf extracts of Zingiber officinale, with nanoparticles formed in the average size range of $10 \mathrm{~nm}$. Synthesis of gold nanoparticles from the extract of the Mirabilis jalapa flower ${ }^{18}$ showed formation of gold nanoparticles with a characteristic size of $100 \mathrm{~nm}$ and spherical in shape. Biomass of Stevia rebaudiana was used for synthesis of gold nanoparticles extracellularly, with nanoparticles in the size range of 8-20 nm. ${ }^{19}$ Huang et al evaluated the prospect of using sundried Cinnamom camphora leaf for the synthesis of nanosized noble metals of gold and silver under ambient conditions..$^{20}$ Aqueous extracts of Withania coagulans, ${ }^{21}$ Cichorium endivia, ${ }^{22}$ Sesbania sesban (L), ${ }^{23}$ Scoparia dulcis, ${ }^{24}$ and Trichosanthes dioica, ${ }^{25}$ as well as the combination of Cassia auriculata and Aegle marmelos ${ }^{26}$ were shown to have hypoglycemic and hypolipidemic effects in animals with experimentally induced diabetes. From the results of the different investigations mentioned above, it is evident that plants act as a natural reservoir for medicinal agents and avoid the common side effects of synthetic chemicals. In this study, green synthesis of gold nanoparticles and aqueous extracts was done from the stem bark of one such potential plant, Cassia fistula (C. fistula), for investigation of its hypoglycemic activity.

C. fistula, a member of the Leguminosae family, has been extensively used in traditional Indian medicine. Different parts of $C$. fistula are reported to have hepatoprotective, anti-inflammatory, antitussive, antifungal, antitumor, antioxidant, and antibacterial activity. ${ }^{27}$ According to the different assays, the barks are known to have a higher antioxidant potential than other parts of the plant. The hypoglycemic and hypocholesterolemic effects of hexane extracts from $C$. fistula were studied by Nirmala et al, ${ }^{28}$ who found a significant decrease in blood glucose levels and improvements in the lipid profile in comparison with the standard reference drug, insulin. These results suggest that the stem barks of hexane extracts from C. fistula possess strong antidiabetic activity.

C. fistula plant organs are known to be an important source of secondary metabolites. The stem bark of the plant acts as a reservoir for lupeol, $\beta$-sitosterol, and hexacosanol. ${ }^{29}$ Rani and Kalidhar reported the presence of oxyanthraquinone and dihydroxyanthraquinone in the bark of the C. fistula plant. ${ }^{30}$ Stem bark of $C$. fistula has a high phenol, flavonoid, and proanthocyanidin phytochemical content. ${ }^{31}$ The present study investigated and compared the hypoglycemic effect of aqueous extract and gold nanoparticles synthesized from the stem bark of $C$. fistula in streptozotocin-induced diabetic rats, based on biochemical parameters.

\section{Materials and methods}

C. fistula belongs to the Leguminosae family. The bark of the C. fistula plant was obtained from a local market. The plant was taxonomically identified and a voucher specimen of the same plant (No HC-15) was authenticated and deposited in our department for future reference. The freshly collected barks were chopped, shade-dried, and coarsely powdered for further extraction. 


\section{Preparation of $C$. fistula aqueous stem bark extract}

We added $12 \mathrm{~mL}$ of double distilled water to a $250 \mathrm{~mL}$ beaker in a magnetic stirrer for 10 minutes, after which we added $60 \mathrm{mg}$ of the weighed plant powder to the water under continuous stirring, and then boiled the mixture at $60^{\circ} \mathrm{C}$ for 15 minutes. The extract obtained was passed through a Whatman filter and used for further experimental work.

\section{Green synthesis of gold nanoparticles from C. fistula stem bark}

The chemicals used for bioreduction of gold to gold nanoparticles $\left(\mathrm{HAuCl}_{4}\right.$-chloroaurate) were purchased from Sigma-Aldrich (St, Louis, MO). Preparation of the gold nanoparticles was done according to the method described by Katti et $\mathrm{al}^{31}$ with slight modifications. Finely coarse powder of C. fistula stem bark was used for phytochemicalmediated synthesis of the gold nanoparticles, whereby $60 \mathrm{mg}$ of bark powder was added to $12 \mathrm{~mL}$ of double distilled water and continuously stirred; $50 \mathrm{~mL}$ of $1 \mathrm{mM}$ aqueous $\mathrm{HAuCl}_{4}$ was subsequently added to the mixture whilst stirring. There was an immediate change in color from brown to ruby red, indicating formation of green gold nanoparticles. The extract was passed through a Whatman filter and the sample was characterized for the size and shape of the nanoparticles formed.

\section{Characterization of phytochemically synthesized gold nanoparticles}

Bioreduction of the gold nanoparticles was monitored using an ultraviolet-visible spectrophotometer. To deduce whether functional groups were present in the sample, Fourier transform infrared (FTIR) spectroscopy was performed. Qualitative analysis was confirmed by scanning electron microscopy.

\section{Ultraviolet visible spectroscopy analysis}

Biological reduction of gold to gold nanoparticles was periodically monitored by the method described by Katti et al using a Lambda UV-650 spectrophotometer (Perkin Elmer, Melville, NY). The ultraviolet-visible spectrophotometer readings were recorded in the nanometer range of 190-900 nm. The samples were diluted with $2 \mathrm{~mL}$ of deionized water and absorbance values were recorded for the samples.

\section{FTIR spectroscopy analysis}

The synthesized gold nanoparticles were lyophilized and mixed with $\mathrm{KBr}$ pellets, and then subjected to a wide range of FTIR spectral analyses (Spectrum RX1, Perkin Elmer). Different peaks were obtained for the test samples.

\section{Scanning electron microscopy of $C$. fistula gold nanoparticles}

The synthesized green gold nanoparticles were characterized using scanning electron microscopy (300-N; Hitachi, Tokyo, Japan). A single drop of the sample was placed on the sample stage, and the aqueous solvent was allowed to evaporate for 5 minutes. The dried sample was coated with gold using an ion sputter-coater with a gold target, and further analyzed for size and shape at different magnifications.

\section{Experimental animals}

Adult male albino Wistar rats weighing 150-200 g bred in the animal division of the King's Institute, Chennai, were used in this study. The animals were acclimatized under appropriate light and dark conditions and fed a standard commercial pellet diet (Sai Enterprises, Chennai, India) and water ad libitum. The experimental protocol was approved by the institution's animal ethics committee.

\section{Chemical compounds}

Streptozotocin was purchased from Sigma Aldrich for experimental induction of diabetes. A freshly prepared solution of streptozotocin $(60 \mathrm{mg} / \mathrm{kg}$ body weight [bw]) in $0.1 \mathrm{M}$ citrate buffer ( $\mathrm{pH} 4.5$ ) was injected intraperitoneally. Seventy-two hours after injection of streptozotocin, rats with blood glucose levels in the range of $175-300 \mathrm{mg} / \mathrm{dL}$ were used for further treatment and analysis, while those rats with blood sugar levels outside the specified range were excluded. Insulin, the standard reference drug, was used for comparison of diabetic animals treated with the plant extract and those treated with the gold nanoparticles. Insulin $3 \mathrm{IU} / \mathrm{kg}$ bw/day was administered to the rats with streptozotocin-induced diabetes.

\section{Study design}

Thirty-five rats ( 30 surviving diabetic rats and five normal rats) were used in this experiment. The rats were divided into seven groups, each containing five rats. Group 1 comprised normal control rats given distilled water only; Group 2 comprised normal rats given aqueous extract of C. fistula $(60 \mathrm{mg} / \mathrm{kg} \mathrm{bw})$ dissolved in $12 \mathrm{~mL}$ of double distilled water via an intragastric tube for 30 days; Group 3 comprised normal rats given phytochemically synthesized gold nanoparticles containing C. fistula $(60 \mathrm{mg} / \mathrm{kg} \mathrm{bw})$ continuously via gastric intubation for 30 days; Group 4 
comprised diabetic controls given a single intraperitoneal injection of streptozotocin $(60 \mathrm{mg} / \mathrm{kg})$, with only distilled water given throughout the experimental period; Group 5 comprised diabetic rats treated with the aqueous extract of C. fistula (60 mg/kg bw) dissolved in $12 \mathrm{~mL}$ of double distilled water, given daily via an intragastric tube for 30 days; Group 6 comprised diabetic rats treated with phytochemically synthesized gold nanoparticles of C. fistula $(60 \mathrm{mg} / \mathrm{kg} \mathrm{bw})$ given continuously via gastric intubation for 30 days; and Group 7 comprised diabetic rats treated with insulin $3 \mathrm{IU} / \mathrm{kg}$ bw throughout the testing period.

The body weight of each animal was recorded before and after induction of diabetes, and after administration of the study treatment. Serum glucose level test was done to determine blood sugar levels. Blood samples were drawn from the tail vein during the course of the experiment. At the end of the experimental period (30 days), the rats were anesthetized with chloroform following a 12-hour fast. Blood samples were drawn by cardiac puncture into plain tubes. The blood samples were centrifuged at $3500 \mathrm{rpm}$ for 20 minutes using a refrigerated centrifuge at $4{ }^{\circ} \mathrm{C}$ (Remi Laboratory Instruments, Mumbai, India). The serum collected was stored at $-20^{\circ} \mathrm{C}$ until needed.

\section{Laboratory measurements}

Serum glucose level test was done on the normal, diabetic, and treated diabetic rats on days 1,15 , and 30 of the experimental period to determine blood glucose levels in the animals. The blood samples collected were centrifuged at $3500 \mathrm{rpm}$ for 20 minutes and serum glucose levels were determined using the glucose oxidase-peroxidase $\operatorname{method}^{32}$ (Coral Clinical Systems, Goa, India). Blood samples were examined to determine glycosylated hemoglobin $\left(\mathrm{HbA}_{1 \mathrm{c}}\right)$ levels using the ion exchange resin method ${ }^{33}$ with kits purchased from Diotek India Ltd, Mumbai, India.

Assays for aspartate transaminase and alanine transaminase were done using the ultraviolet kinetic (International Federation of Clinical Chemistry) method ${ }^{34,35}$ with commercial kits (Autopak) obtained from Bayer Diagnostics Baroda, India. An alkaline phosphatase assay was also performed using the p-nitro phenyl phosphate method with Autopak diagnostic kits.

Serum albumin was determined using the bromcresol green method with an Autopak kit. The total protein present in serum was estimated by the Biuret method ${ }^{36}$ using an Autopak kit. Globulin levels were calculated from total protein and albumin measurements. Serum urea, ${ }^{37}$ creatinine, ${ }^{38}$ and uric acid ${ }^{39}$ levels were determined using diagnostic kits from Biosystems, Barcelona, Spain. Serum lipid profiles ${ }^{40}$ were determined using reagent kits purchased from (Piramel Health care, Mumbai, India).

\section{Statistical analysis}

The statistical analysis was performed using SPSS software (v 17; SPSS Inc, Chicago, IL). The values were analyzed by one-way analysis of variance followed by Duncan's multiple range test. The results are represented as the mean \pm standard error of the mean for five rats. $P$ values $<0.05$ were considered to be statistically significant.

\section{Results}

The results of the ultraviolet-visible spectroscopic analysis of the aqueous extract and gold nanoparticles from the $C$. fistula plant are shown in Figure $1 \mathrm{~A}$ and $\mathrm{B}$. The characteristic absorbance peak for the aqueous plant extract was obtained at $236 \mathrm{~nm}$ whereas the absorbance peak observed for the gold nanoparticles was at $529 \mathrm{~nm}$.

Figure 2A and B represents the FTIR spectral analysis for both the aqueous and gold nanoparticles. Characteristic functional groups responsible for formation of the particles in the samples were recorded.

Scanning electron microscopic images are shown in Figure 3. Figure 3A shows the gold nanoparticles formed as a result of reduction of gold ions. The image was taken at a magnification of $3000 \times$. Figure $3 \mathrm{~B}$ shows a closer view of the nanoparticles formed at a magnification of $8000 \times$. Figure $3 \mathrm{C}$ shows the shape of the nanoparticles formed. Particles of different shapes were formed as a result of reduction of gold ions to gold nanoparticles by $C$. fistula $(16,000 \times)$. Figure 3D shows the varying sizes of the nanoparticles, which were in the range of 55.2-98.4 $\mathrm{nm}(23,000 \times)$.

The body weights of the different groups of animals were in the range of 150-200 $\mathrm{g}$ (Figure 4). There was a reduction in body weight after induction of diabetes by streptozotocin. The mean body weight of the animals after 30 days of treatment with aqueous extract, gold nanoparticles, and insulin was $151.60 \pm 10.27 \mathrm{~g}, 178.80 \pm 9.78 \mathrm{~g}$, and $178.00 \pm 2.00 \mathrm{~g}$, respectively. The weight of the non-diabetic rats when treated with aqueous extract and with gold nanoparticles remained the same.

The serum glucose levels for the normal, diabetic, and treated diabetic animals are shown in Figure 5. The initial mean serum glucose levels for the seven groups of rats were in the range of 95-110 mg/dL. Fasting serum glucose levels after administration of streptozotocin showed an increase in blood glucose levels. On treating the animals with the aqueous extract or gold nanoparticles for 


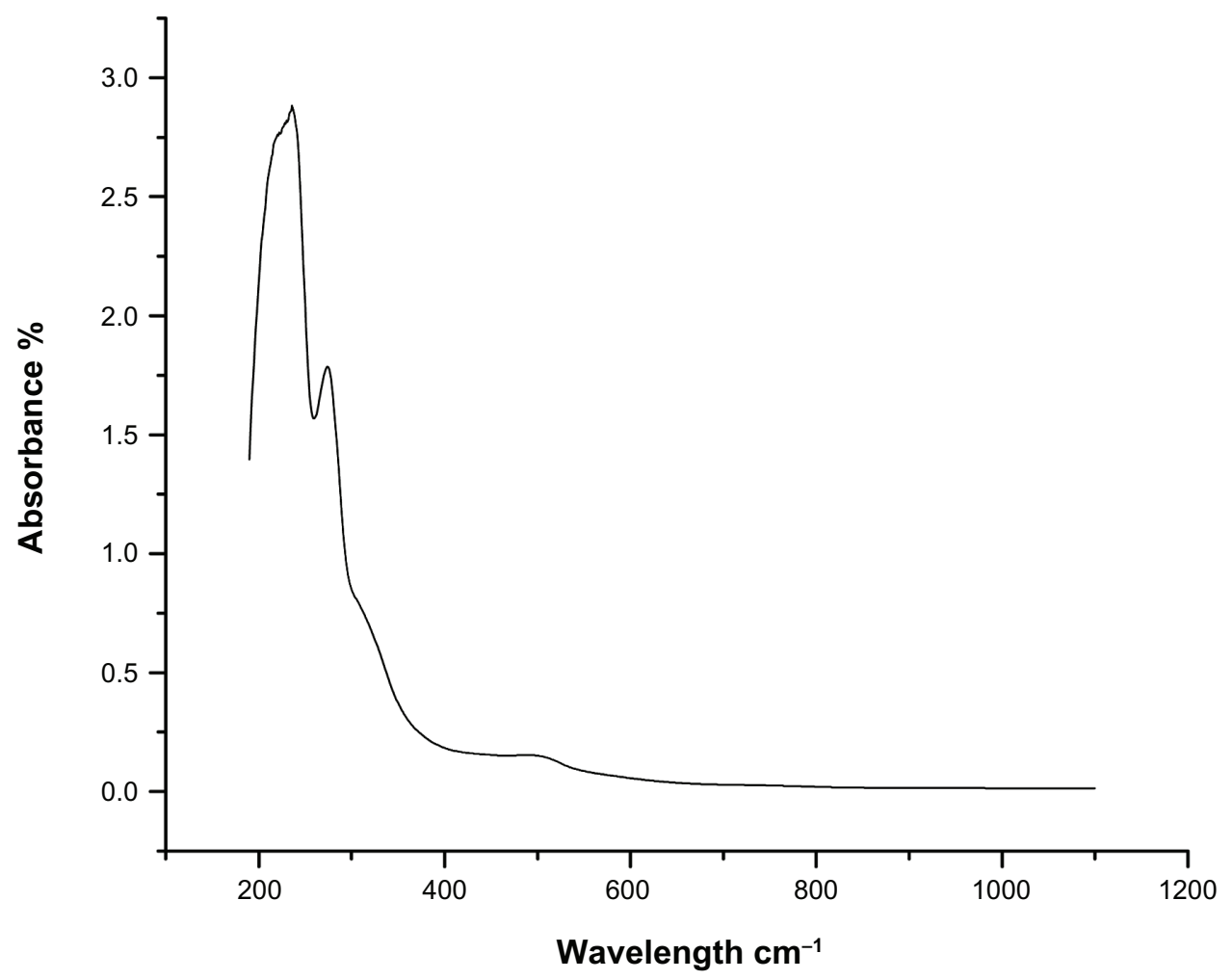

Figure IA Ultraviolet-visible spectroscopic analysis of aqueous extract of the medicinal plant Cassia fistula.

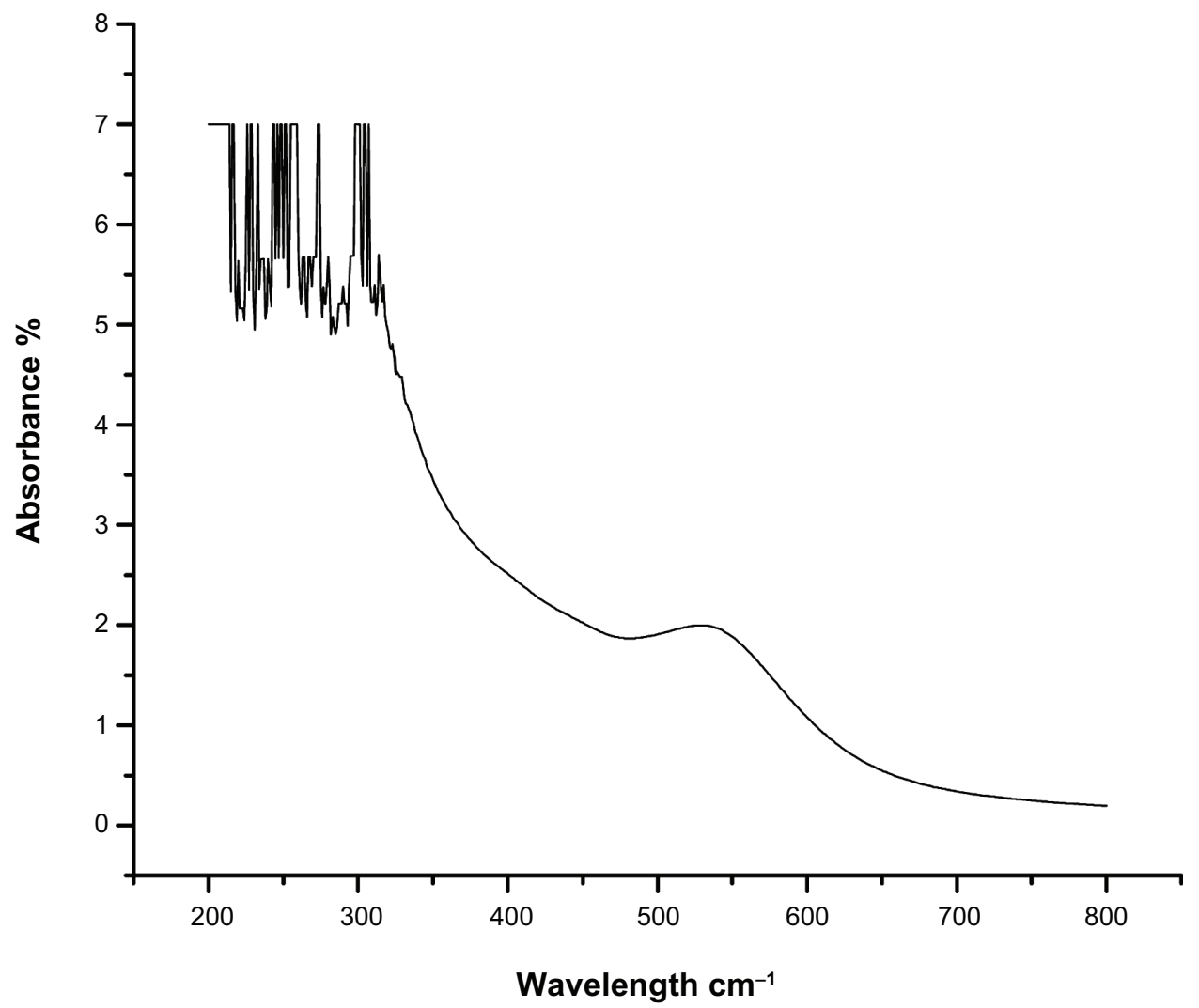

Figure IB Ultraviolet-visible spectroscopic analysis of gold nanoparticles from the medicinal plant Cassia fistula. 


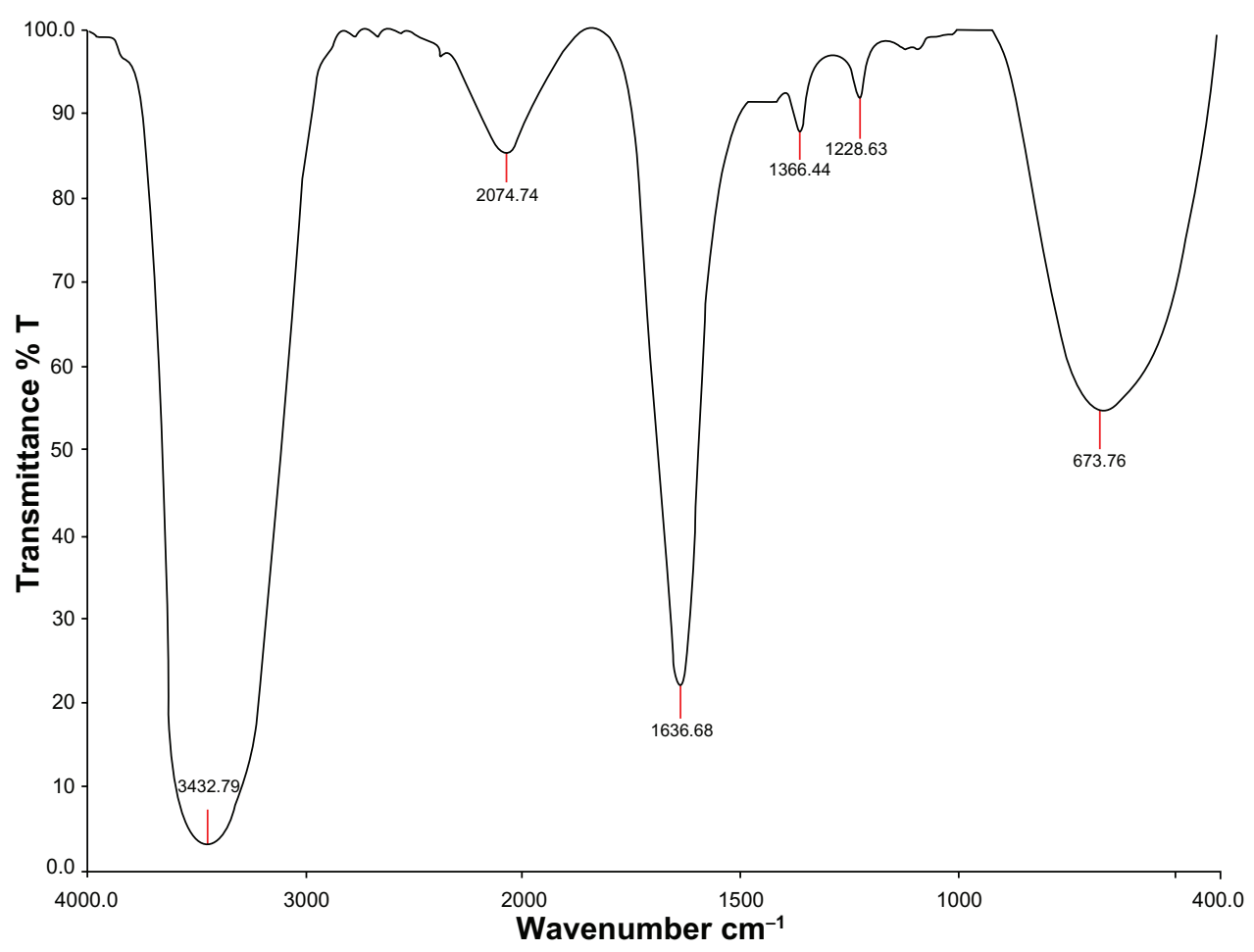

Figure 2A Characteristic Fourier transform infrared absorption spectra for aqueous extract of Cassia fistula.

30 days, blood sugar levels were $211.05 \pm 5.40 \mathrm{mg} / \mathrm{dL}$ and $168.47 \pm 16.18 \mathrm{mg} / \mathrm{dL}$, respectively. Rats that also received insulin showed a decrease in blood sugar levels. In the diabetic control rats, blood sugar levels reached a peak by the end of the experimental period.

Mean $\mathrm{HbA}_{1 \mathrm{c}}$ levels in normal rats were $6.49 \% \pm 0.13 \%$ (Figure 6). There was a significant increase in total hemoglobin in the diabetic control rats $(13.59 \% \pm 0.28 \%)$. After treatment with the aqueous extract or the gold nanoparticles, the animals showed a decrease in $\mathrm{HbA}_{1 \mathrm{c}}$ levels to $11.45 \% \pm 0.28 \%$ and $10.40 \% \pm 0.23 \%$, respectively. The diabetic rats also treated with insulin showed a restoration in $\mathrm{HbA}_{1 \mathrm{c}}$ levels. In rats treated with gold nanoparticles, $\mathrm{HbA}_{1 \mathrm{c}}$ levels were found to be in the near normal range.

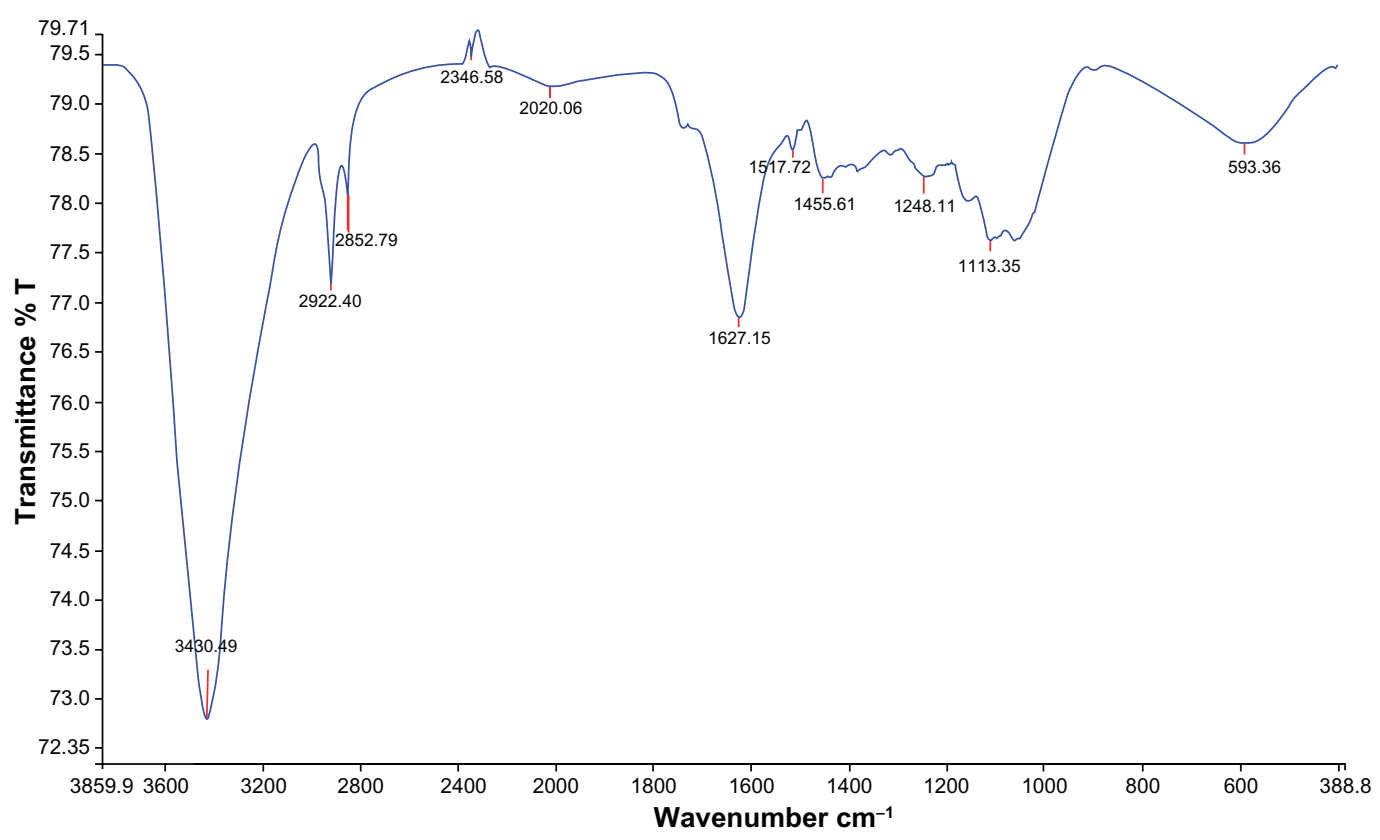

Figure 2B Characteristic Fourier transform infrared absorption spectra for Cassia fistula after bioreduction of gold ions to gold nanoparticles. 

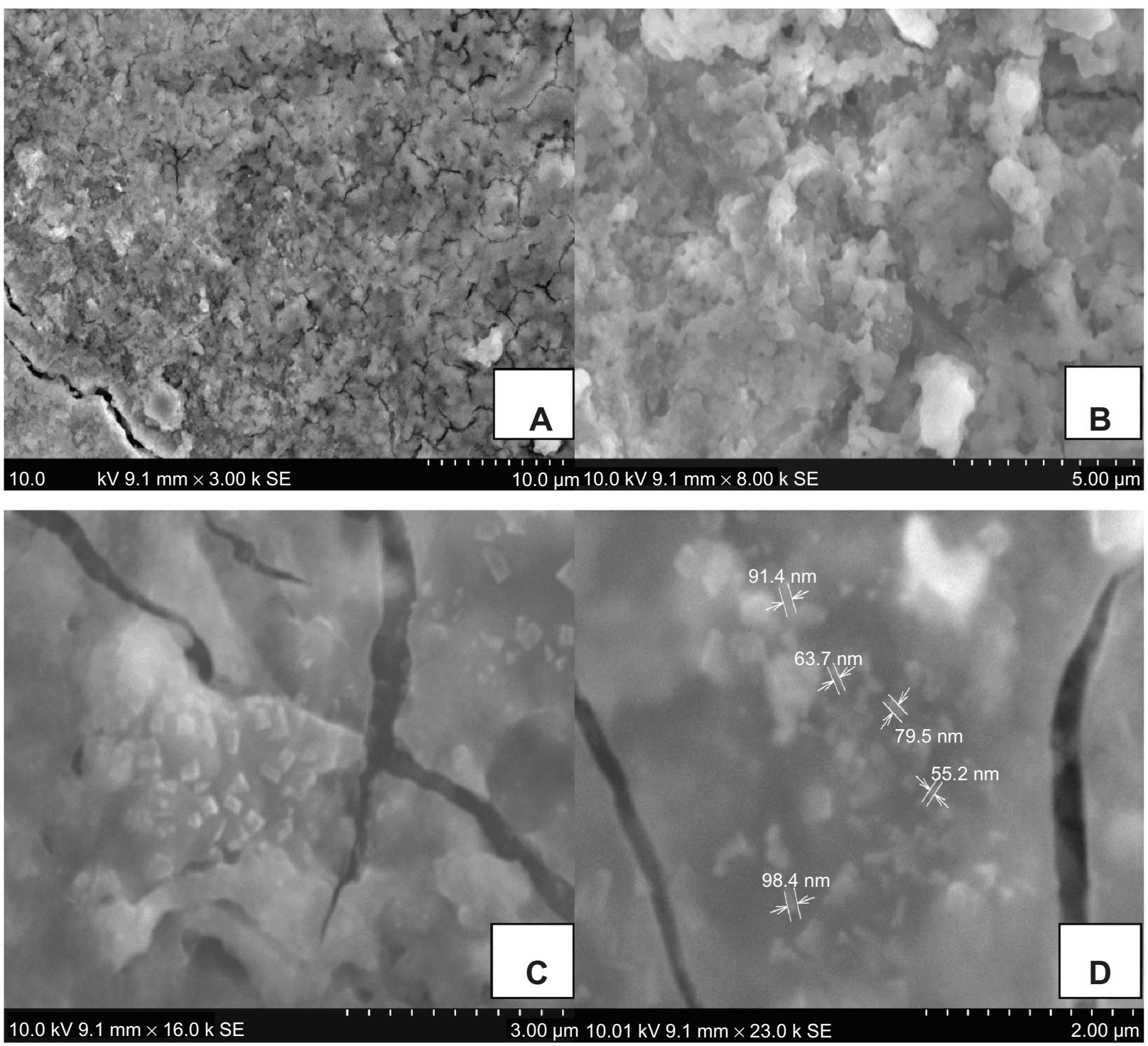

Figure 3 Scanning electron microscopic images of phytochemically synthesized gold nanoparticles. (A) and (B) Formation of gold nanoparticles by reduction of gold ions. (C) Different shapes of particles formed (16,000x) and (D) nanometer size of gold nanoparticles (23,000x)

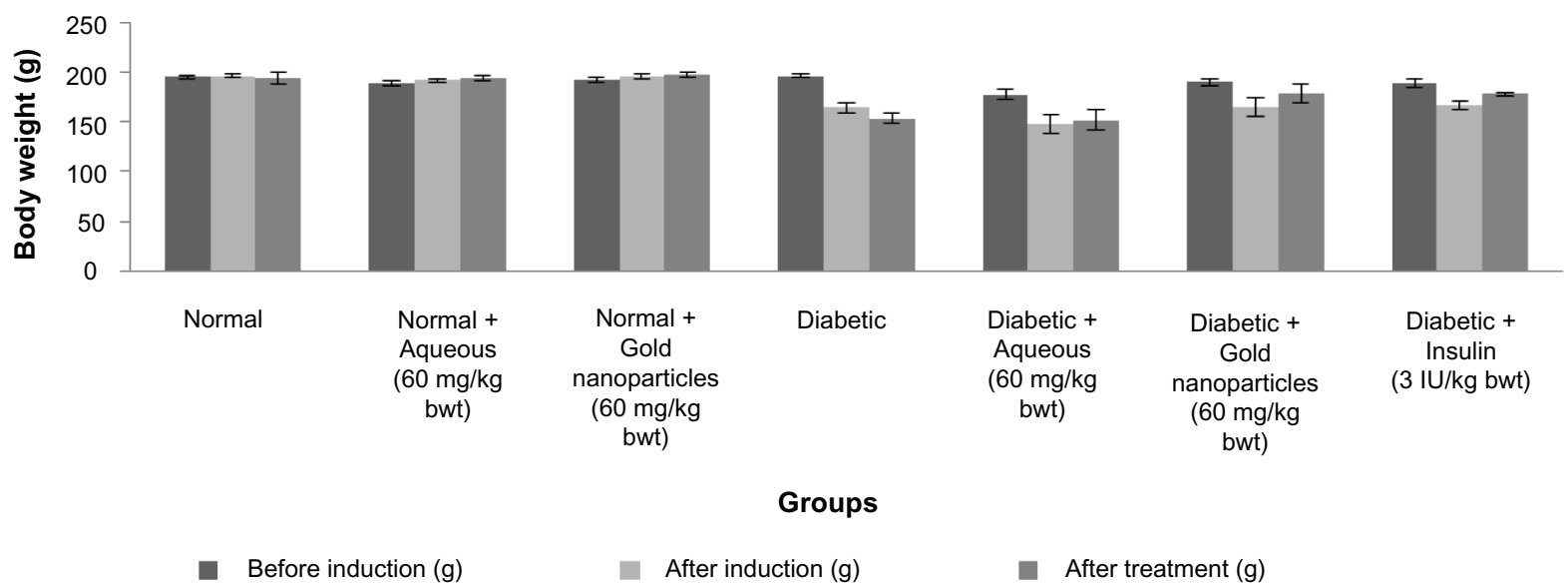

Figure 4 Effect of aqueous and gold nanoparticles on body weight of normal, nondiabetic, and diabetic male albino Wistar rats. Each value represents the mean \pm standard error of the mean $(n=5)$. The values were found to be statistically significant at $P<0.05$. 


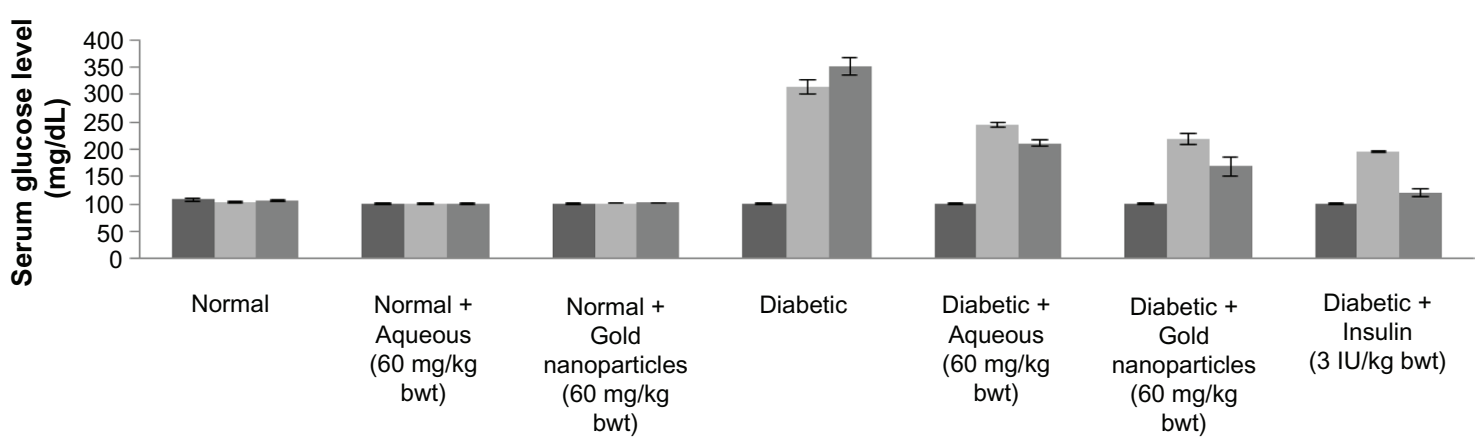

Groups

Day $1(\mathrm{mg} / \mathrm{dL}) \quad$ Day $15(\mathrm{mg} / \mathrm{dL}) \quad$ Day $30(\mathrm{mg} / \mathrm{dL})$

Figure 5 Serum glucose levels in normal, diabetic and diabetic treated male albino Wistar rats after 30 days of treatment. Each value represents the mean \pm standard error of the mean $(n=5)$.

Note: The values were found to be statistically significant at $P<0.05$.

A decrease in aspartate transaminase, alanine transaminase, and alkaline phosphatase levels and an increase in concentrations of albumin, globulin, and total protein were found in the diabetic rats treated with aqueous extract and gold nanoparticles, as shown in Figure 7. There was a significant increase in serum albumin, globulin, and total protein content in the treated diabetic rats compared with the diabetic controls. The mean total protein content in rats treated with the aqueous extract was $5.60 \pm 0.56 \mathrm{mg} \%$, which was slightly lower than the total protein content in rats treated with the gold nanoparticles $(6.41 \pm 0.41 \mathrm{mg} \%)$.

There was a marked decrease in aspartate transaminase levels in the treated diabetic rats when compared with the diabetic control rats whose aspartate transaminase level was found to be $99.8 \pm 1.68 \mathrm{mg} \%$. Serum alanine transaminase levels are shown in Figure 7, and indicate a significant reduction in mean activity from $95.78 \pm 0.83$ to $84.34 \pm 2.02 \mathrm{mg} \%$ in comparison with alanine transaminase levels in the untreated diabetic rats, which had a higher mean enzyme activity at $118.78 \pm 1.49 \mathrm{mg} \%$. The rats also treated with insulin had lower enzyme levels. The animals treated with gold nanoparticles showed a highly significant decrease in alanine transaminase to near normal levels, similar to that seen in the insulin-treated rats. Figure 7 shows that alkaline phosphatase underwent a significant reduction to near normal levels in response to treatment with the aqueous

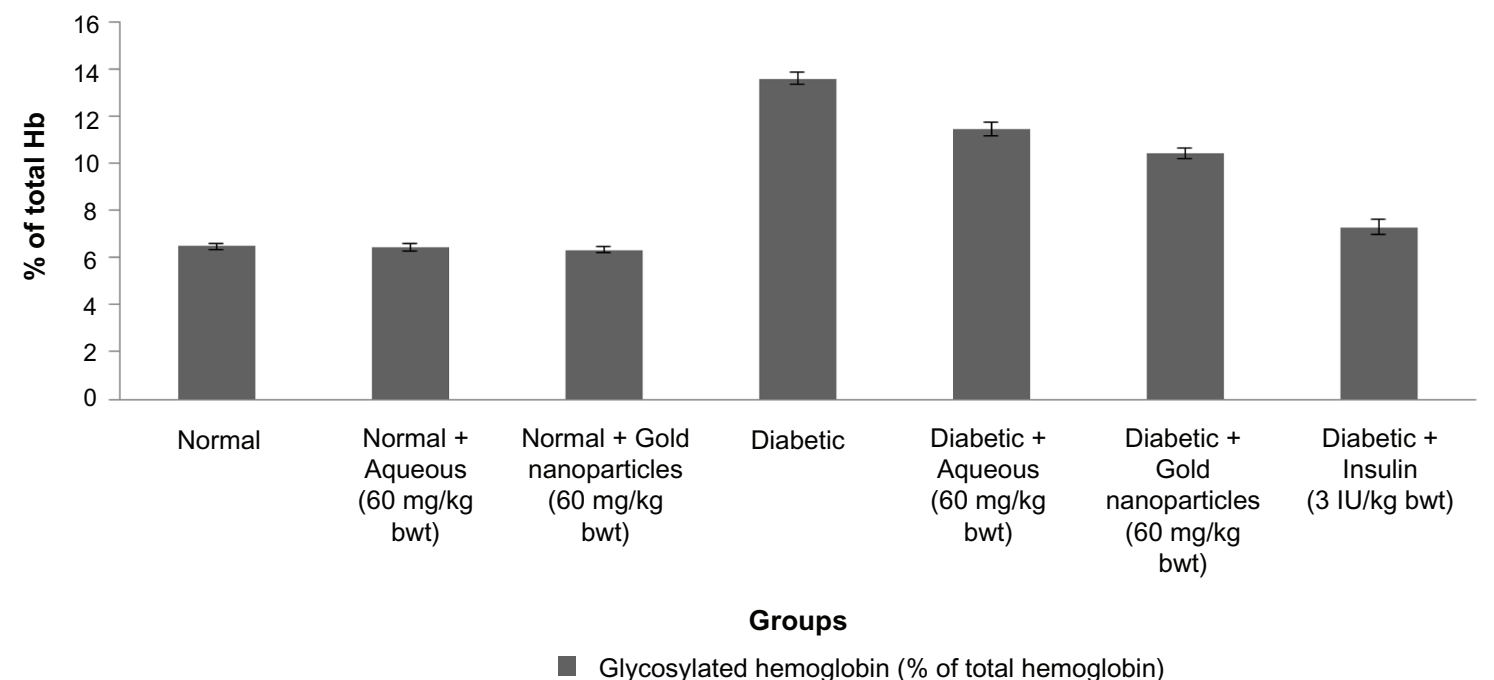

Figure 6 Percentage of total hemoglobin after 30 days of treatment with aqueous extract or gold nanoparticles from Cassia fistula in controls and rats with streptozotocininduced diabetes.

Notes: Each value represents the mean \pm standard error of the mean $(n=5)$. The values were found to be statistically significant at $P<0.05$. 


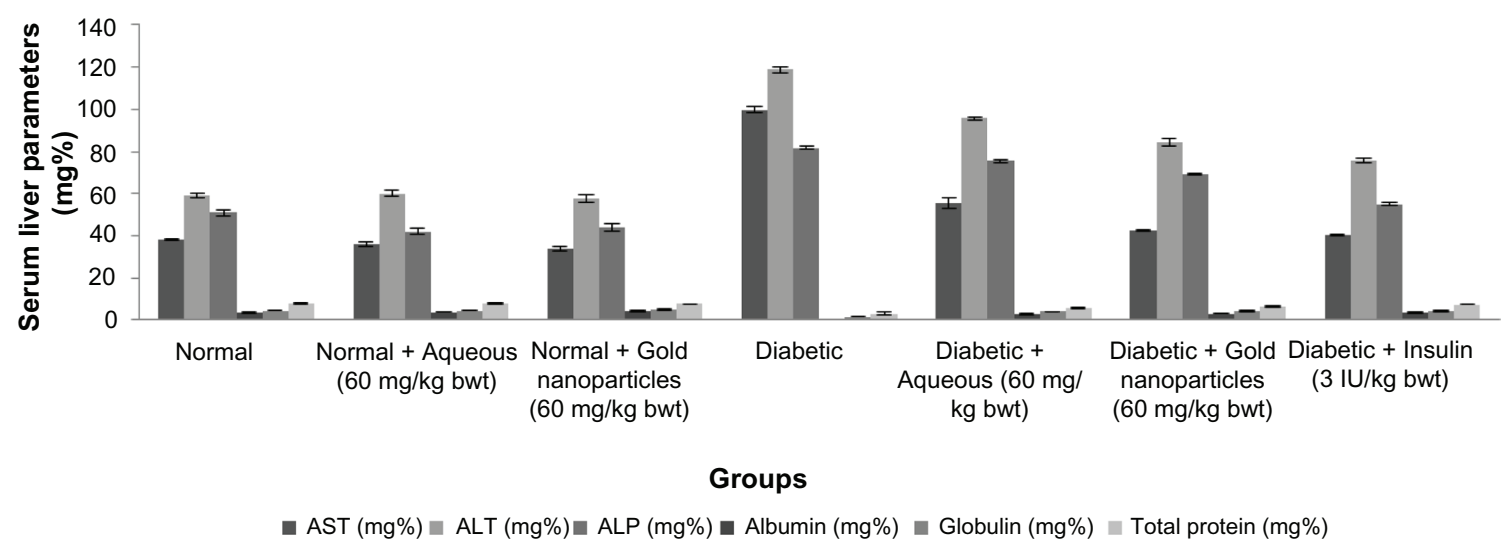

Figure 7 Total liver concentration of normal, diabetic and diabetic treated rats after 30 days of treatment.

Notes: Each value represents the mean \pm standard error of the mean $(n=5)$. The values were found to be statistically significant at $P<0.05$.

Abbreviations: ALP, alkaline phosphatase; ALT, alanine transaminase; AST, aspartate transaminase.

extract or gold nanoparticles of $C$. fistula after continuous administration for 30 days. The maximum decrease was observed in rats also receiving insulin, with the next largest decrease in alkaline phosphatase activity seen in the group treated with gold nanoparticles.

Serum urea, creatinine, and uric acid levels are shown in Figure 8, and were comparatively high in the diabetic control rats. On continuous treatment with $C$. fistula, there was a highly significant decrease in urea, creatinine, and uric acid levels in diabetic rats treated with the aqueous extract or gold nanoparticles, and a return to near normal levels.

Lipid profiles (total cholesterol, triglycerides, low-density lipoprotein, very low-density lipoprotein, and high-density lipoprotein) for the normal, treated nondiabetic rats, diabetic controls, and treated diabetic rats are shown in Figure 9. The serum lipid profile reached a peak in diabetic control rats, whereas the level of high-density lipoprotein decreased.
After continuous treatment with the plant extract for 30 days, rats with streptozotocin-induced diabetes showed a marked decrease in cholesterol levels with a significant increase in high-density lipoprotein.

\section{Discussion}

The present work was carried out to compare the efficacy of phytochemically synthesized green gold nanoparticles with that of an aqueous extract of $C$. fistula as hypoglycemic treatment for diabetes mellitus and its complications. Biochemical parameters were assessed to support the proposed hypothesis.

Diabetes mellitus is a common metabolic disease characterized by increased circulating glucose concentrations. It is associated with a variety of microvascular, macrovascular, neurological, and infectious complications, including abnormal carbohydrate, fat, and protein metabolism.

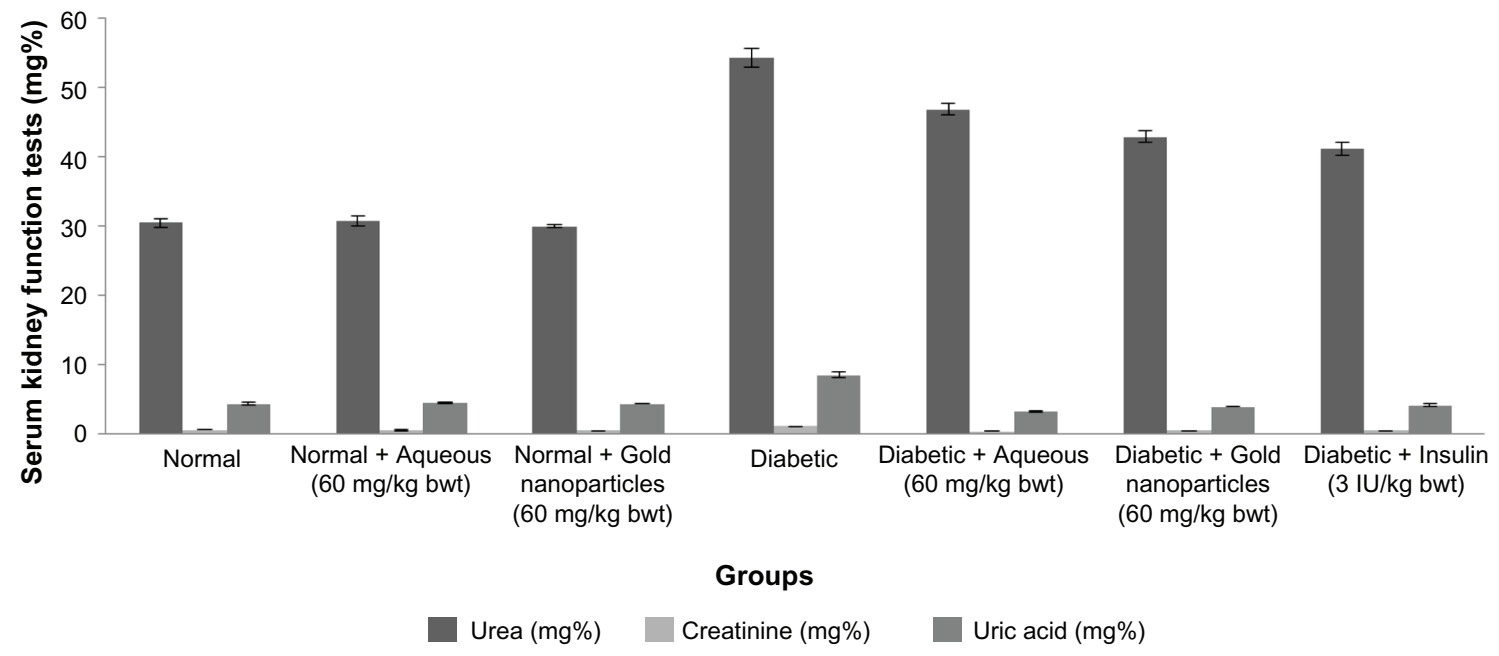

Figure 8 Serum urea, creatinine and uric acid levels of aqueous and gold nanoparticles of $C$. fistula on different groups of male albino Wistar rats. Notes: Each value represents the mean \pm standard error of the mean $(n=5)$. The values were found to be statistically significant at $P<0.05$. 


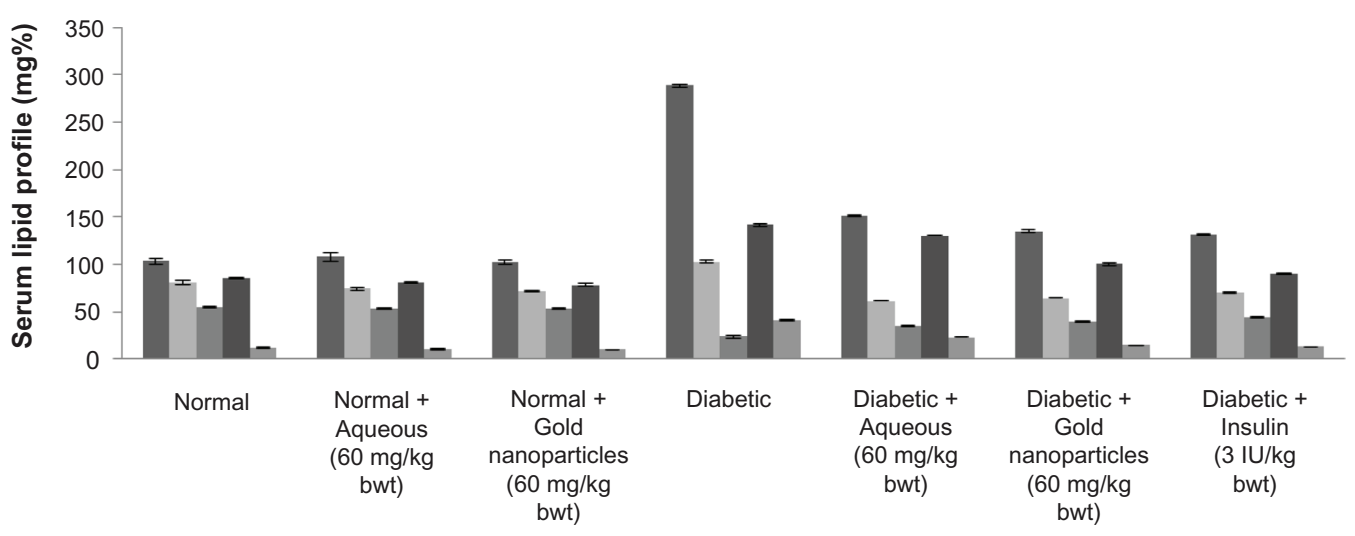

Groups

- Total cholesterol (mg\%)

- Triglycerides $(\mathrm{mg} \%)$

- HDL $(\mathrm{mg} \%)$

- $\mathrm{LDL}(\mathrm{mg} \%)$

- VLDL $(\mathrm{mg} \%)$

Figure 9 Lipid profile of experimental animals after 30 days of treatment with aqueous extract or gold nanoparticles from Cassia fistula.

Notes: Each value represents the mean \pm standard error of the mean $(n=5)$. The values were found to be statistically significant at $P<0.05$.

Abbreviations: HDL, high-density lipoprotein; LDL, low-density lipoprotein; VLDL, very low-density lipoprotein.

Streptozotocin-induced diabetes is a well documented model of experimental diabetes, providing a relevant example of endogenous chronic oxidative stress due to hyperglycemia. ${ }^{41}$ Streptozotocin is often used to induce diabetes mellitus in experimental animals because of its toxic effect on pancreatic $\beta$ cells. ${ }^{42,43}$ In the present study, a single intraperitoneal injection of streptozotocin $60 \mathrm{mg} / \mathrm{kg}$ bw was administered to the experimental animals resulting in toxicity to $\beta$ cells, with emergence of clinical diabetes within 2-4 days. ${ }^{44}$

Nanotechnology can be defined as research on the design, synthesis, and structural manipulation of particles with dimensions smaller than $100 \mathrm{~nm}$. Biosynthesis of gold nanoparticles with the help of medicinal plants has come into the limelight in nanobiotechnology due to the growing need to develop environmental friendly benign technologies. Plants are an excellent source of secondary metabolites, and have been found to be cost-effective and ecofriendly for the large-scale synthesis of nanoparticles..$^{45}$ In this study, C. fistula was used for preparation of an aqueous extract and also for bioreduction of gold ions into gold nanoparticles. The reduction of chloroaurate ions to nanoparticles was more rapid upon addition of the plant biomass to the aqueous solution of $\mathrm{HAuCl}_{4} \cdot \mathrm{Au}^{3+}$, according to Padma and Bajpai, ${ }^{18}$ is a soft metal which binds to a biomass mainly via amino and sulfhydryl groups, which are considered to be soft ligands and carry more positive charge at low $\mathrm{pH}$ values, making them available for the binding and reduction of $\mathrm{Au}^{3+}$ to gold. Investigators have previously reported that formation of pure metallic nanoparticles and bimetallic nanoparticles by the reduction of metal ions is possibly facilitated by reducing sugars and/or terpenoids. In this study, reduction of chloroaurate ions could have occurred due to the presence of secondary metabolites, such as lupeol, $\beta$-sitosterol, and hexacosanol, in the stem bark of C. fistula.

Ultraviolet-visible spectroscopy is an indirect method for determining the reduction of gold ions to gold nanoparticles. In certain metals, such as silver and gold, plasmon resonance is responsible for their unique and remarkable optical phenomena. Figure 1A and B show ultraviolet-visible spectra for aqueous extract and gold nanoparticles from C. fistula. The surface plasmon resonance band was obtained at $236 \mathrm{~nm}$ for the aqueous extract whereas the characteristic peak occurred at around $529 \mathrm{~nm}$ after 2 hours of reaction time for the phytochemically synthesized gold nanoparticles. Fierascu et $\mathrm{al}^{46}$ investigated the synthesis of gold nanoparticles from neem extract, which possessed a characteristic absorption peak at $525 \mathrm{~nm}$. The bioreduction of gold ions occurred at much more rapid rate, and Shankar et $\mathrm{al}^{47}$ reported that the surface plasmon band arises from existence of free electrons in the conduction band due to the small particle size. The surface plasmon resonance peak in the ultraviolet absorption spectrum is shown by these plasmon resonant particles. ${ }^{48}$ To determine whether specific functional groups could be responsible for the bioreduction, FTIR spectra for the aqueous extract and gold nanoparticles were obtained. Figure 2A and B represent the FTIR spectral data for aqueous extract and gold nanoparticle samples from the stem bark of $C$. fistula. The vibrational spectrum for a molecule of the aqueous extract is shown in Figure 2A. Several absorption peaks are centered around 3432.79, 2074.74, 
1636.68, 1366.44, 1228.63, and $673.76 \mathrm{~cm}^{-1}$, which are attributable to the stretching vibrations of the $\mathrm{O}-\mathrm{H}$ group at $3432.71 \mathrm{~cm}^{-1}$. Other characteristic stretching modes are found at $2074.74 \mathrm{~cm}^{-1}$ for $\mathrm{N}-\mathrm{H}$ amines, $1636.68 \mathrm{~cm}^{-1}$ for $\mathrm{C}-\mathrm{C}$ stretch (in the ring), $1366.44 \mathrm{~cm}^{-1}$ for the $\mathrm{C}-\mathrm{H}$ bend, and $\mathrm{C}-\mathrm{O}$ stretch mode at $1228.63 \mathrm{~cm}^{-1}$ and $\mathrm{C}-\mathrm{Br}$ stretch at $673.76 \mathrm{~cm}^{-1}$. FTIR spectral data for the biosynthesized gold nanoparticles of $C$. fistula (Figure 2B) are attributable to the $\mathrm{O}-\mathrm{H}$ group at $3430.49 \mathrm{~cm}^{-1}$. A C-H stretch exists in the region of $2850-3000 \mathrm{~cm}^{-1}$. Peaks at $1627.15 \mathrm{~cm}^{-1}$, $1517.72 \mathrm{~cm}^{-1}$, and $1455.61 \mathrm{~cm}^{-1}$ can be assigned to $\mathrm{N}-\mathrm{H}$ bending, $\mathrm{N}-\mathrm{O}$ asymmetric stretching, and $\mathrm{C}-\mathrm{C}$ stretching (in the ring). Stretching at $1248.11 \mathrm{~cm}^{-1}$ and $1113.35 \mathrm{~cm}^{-1}$ contributes to the $\mathrm{C}-\mathrm{N}$ stretching mode (aliphatic amines). Agnieszka et al ${ }^{49}$ reported a characteristic stretch at $3437 \mathrm{~cm}^{-1}$ from a hydroxyl group through synthetic preparation of gold nanoparticles using the sodium citrate reduction method. ${ }^{50}$

Figure 3A-D represents the surface architecture of gold nanoparticles as a result of bioreduction of $C$. fistula, captured at different magnifications under a scanning electron microscope. At high resolution values, the nanoparticles were found to be polydispersed with rectangular and triangular shapes. The average size of the nanoparticles was in the range of 55.2-98.4 nm. Our scanning electron microscopy results are consistent with those of Elavazhagan and Arunachalam, ${ }^{51}$ who reported formation of gold nanoparticles in the size range of 50-80 $\mathrm{nm}$ on reduction by Memecylon edule leaf biomass.

In our present study, biochemical parameters were unchanged in nondiabetic rats treated with the aqueous extract of $C$. fistula and gold nanoparticles synthesized from the same plant. There was a significant decrease in body weight in the animals with streptozotocin-induced diabetes. This finding is consistent with that of Shirwaikar et $\mathrm{al}^{52}$ who reported that diabetes mellitus is attributable to gluconeogenesis associated with a characteristic loss of body weight as a result of increased muscle wasting and loss of tissue proteins; this might also be attributable to dehydration and fat catabolism, as reported by Hakim et al. ${ }^{53}$ Oral administration of aqueous extract and biosynthetic gold nanoparticles achieved a remarkable improvement in body weight. There was a better body weight increment in animals treated with the gold nanoparticles than in those treated with the aqueous extract. The possible underlying mechanism for this gain in body weight is the effect of controlling muscle wasting, ie, reversal of antagonism. ${ }^{54}$

Serum glucose levels increased in rats with streptozotocininduced diabetes but not in nondiabetic rats. Streptozotocin is used to induce diabetes mellitus via a selective cytotoxic effect on pancreatic $\beta$ cells, triggering endogenous release of insulin and a consequent increase in blood glucose levels. ${ }^{55}$ Our findings are in accordance with those of several other investigators in animals with streptozotocin-induced diabetes.

In the present study, animals with streptozotocin-induced diabetes showed marked reductions in blood glucose levels after 4 weeks of continuous administration of aqueous extract or gold nanoparticles. Possible underlying mechanisms by which the plant material controlled the increasing blood glucose levels are potentiation of pancreatic secretion of insulin from $\beta$ cells in the islets of Langerhans ${ }^{56}$ and increased transport of blood glucose to peripheral tissues. ${ }^{57}$ Our results are in accordance with those of Nirmala et al, ${ }^{28}$ who reported an increase in insulin secretion and decreased blood glucose levels in animals with streptozotocin-induced diabetes treated with hexane extracts of stem bark from $C$. fistula.

The glucose-lowering effect of the experimental treatments was compared with that of insulin. Insulin was found to be more effective than the aqueous extract and gold nanoparticles in reducing blood glucose levels. The gold nanoparticles were the most effective after insulin in lowering blood glucose levels. Our findings are consistent with those of Bharathmanikanth et al, ${ }^{58}$ who treated diabetic rats with gold nanoparticles at a dose of $2.5 \mathrm{mg} / \mathrm{kg}$.

In controlled or poorly controlled diabetes, there is increased glycosylation of a number of proteins, including hemoglobin. ${ }^{59}$ Increased serum $\mathrm{HbA}_{1 \mathrm{c}}$ levels in rats with streptozotocin-induced diabetes suggest an increased rate of alkylation and free radical formation. In this study, there was a significant decrease in $\mathrm{HbA}_{1 \mathrm{c}}$ levels down to the near normal range in diabetic animals treated with the $C$. fistula aqueous extract or gold nanoparticles. Our $\mathrm{HbA}_{1 \mathrm{c}}$ data corroborate those of Oluba et al, ${ }^{60}$ who reported that Ganoderma lucidum extracts achieve a significant reduction in $\mathrm{HbA}_{1 \mathrm{c}}$, which could have possibly occurred as a result of antioxidant activity in the plants. Oral administration of the aqueous extract and gold nanoparticles had an effect on $\mathrm{HbA}_{1 \mathrm{c}}$, by preventing its elevation. C. fistula may also possess antioxidant activity, which would have scavenged free radicals, leading to a significant decrease in $\mathrm{HbA}_{1 \mathrm{c}}$ in diabetic rats. Gold nanoparticles derived from $C$. fistula were found to be effective in restoring $\mathrm{HbA}_{1 \mathrm{c}}$ to normal levels, probably as a result of efficient scavenging activity.

The increased transaminase levels indicate hepatic dysfunction in animals with streptozotocin-induced diabetes. Aspartate transaminase and alanine transaminase are released 
when injury involves organelles such as the mitochondria. ${ }^{61}$ Transaminases mediate the catalysis of amino transfer reactions, and are vital markers of liver injury in clinical diagnostics. ${ }^{62}$ Alkaline phosphatase is a hydrolase enzyme located in the cytoplasm, ${ }^{63}$ and is responsible for removing phosphate from nucleotides and proteins released due to hepatic cellular damage. Assessment of marker enzyme (aspartate transaminase, alanine transaminase, and alkaline phosphatase) levels in streptozotocin-induced diabetic rats showed an elevation resulting from leakage of enzymes into the bloodstream. ${ }^{64}$ In the present investigation, there was a progressive increment in aspartate transaminase, alanine transaminase, and alkaline phosphatase levels in the diabetic rats. Gold nanoparticles are believed to play a protective role in the decrease of transaminase levels. Our results are in line with those of Patrick et $\mathrm{al}^{65}$ and Mahmoud et al, ${ }^{66}$ who reported an inhibitory effect of different plant extracts on transaminase activity.

Serum albumin and globulin levels were markedly decreased in the diabetic control group. Total protein levels are significantly decreased in rats with streptozotocin-induced diabetes due to increased protein catabolism. ${ }^{67}$ The present study found that daily administration of an aqueous extract or gold nanoparticle sample from $C$. fistula to diabetic rats gradually increased their protein levels, and that the gold nanoparticles had a pronounced effect on protein content, with results for total protein being in accordance with those of Akah et $\mathrm{al}^{68}$ who reported that fraction 6 of Vernonia amygdalina leaf extracts was capable of normalizing total protein and albumin levels in rats with streptozotocin-induced diabetes.

Diabetes affects both glucose and lipid metabolism. ${ }^{69}$ The abnormally high concentration of serum lipids in diabetes is mainly due to an increase in mobilization of free fatty acids from peripheral fat depots. ${ }^{70}$ The present investigation shows an increase in serum lipoproteins (total cholesterol, triglycerides, low-density lipoprotein, very low-density lipoprotein). Such an increase in lipid content increases the risk of coronary heart disease and atherosclerosis.

Treatment of animals with streptozotocin-induced diabetes with gold nanoparticles from C. fistula and also with its aqueous extract returned lipid levels back to near normal. This improvement may be attributable to the cardioprotective properties of $\beta$ sitosterol, a plant sterol present in the stem bark of $C$. fistula. Our data on the lipid profile run parallel with the results of Nirmala et $\mathrm{al}^{28}$ who reported an improved lipid profile in rats with streptozotocin-induced diabetes treated with hexane extracts from C. fistula stem bark.
The lipid-lowering effects of gold nanoparticles were found to be more effective than those of the aqueous extract. High-density lipoprotein levels were significantly increased, indicating a reversed atherogenic risk which might be due to increased activity of lecithin cholesterol acyltransferase, which in turn contributes to regulation of serum lipids. ${ }^{71}$

Diabetic hyperglycemia produces elevation of plasma levels of urea and creatinine which are considered to be significant markers of renal dysfunction. ${ }^{72}$ Urea, creatinine, and uric acid levels were elevated in diabetic rats during the present experiment, indicating impaired renal function. On administering gold nanoparticles and aqueous extracts for 30 days, serum urea, creatinine and uric acid levels steadily returned to near normal. These results are in agreement with those of Daisy et $\mathrm{al}^{73}$ who reported that renal markers in serum were decreased on administration of crude hexane extracts from Costus speciosus to animals with streptozotocin-induced diabetes. Administering gold nanoparticles orally to diabetic rats decreased serum urea, creatinine, and uric acid more effectively, and could be explained by the regenerative ability of the renal tubules. ${ }^{74}$

\section{Conclusion}

Reduction of gold ions by C. fistula stem bark resulted in the formation of stable nanoparticles with different morphologies. Use of gold nanoparticles synthesized from C. fistula stem bark for the treatment of rats with streptozotocin-induced diabetes reduced serum blood glucose concentrations, induced favorable changes in body weight, improved transaminase activity, achieved a better lipid profile, and reversed renal dysfunction to a greater extent that did aqueous extracts from the same plant. This study indicates that phytochemically synthesized gold nanoparticles are better hypoglycemic agents in the treatment of diabetes mellitus and its associated complications.

\section{Disclosure}

The authors report no conflicts of interest in this work.

\section{References}

1. Barar FS. Essentials of Pharmacotherapeutics. 3rd ed. New Delhi: S Chand and Company Ltd; 2004.

2. Prajapati DD, Patel NM, Savadi RV, Akki KS, Mruthunjaya K. Alleviation of alloxan-induced diabetes and its complications in rats by Actinodaphne hookeri leaf extract. 2008;3:102-106.

3. Wild SG, Roglic A, Green R, King H. Global prevalence of diabetes. Estimated for the year 2000 and projection for 2030. Diabetes Care. 2004;27:1047-1054.

4. Sona PS. Nanoparticulate drug delivery system for the treatment of diabetes. Digest Journal of Nanomaterials and Biostructures. 2010;5:411-418. 
5. Rajalakasmi M, Eliza J, Cecilia E, Nirmala A, Daisy P. Antidiabetic properties of Tinospora cordifolia stem extracts on streptozotocininduced diabetic rats. African J Pharmacol. 2009;3:171-180.

6. Donath MY, Ehses JA. Type 1, type 1.5, and type 2 diabetes: NOD the diabetes we thought it was. Proc Natl Acad Sci U S A. 2006;103. 12217-12218.

7. Noor A, Gunasekaran S, Manickam AS, Vijayalakshmi MA. Anti-diabetic activity of Aloe vera and histology of organs in STZ-induced diabetic rats. Curr Sci. 2008;94:1070-1076.

8. Bailey CJ. New pharmacological approaches to glycaemic control. Diabetes Review. 1999;7:94-113.

9. Andeani JK, Kazemi H, Mohsenzadeh S, Safavi A. Biosynthesis of gold nanoparticles using dried flower extracts of Achillea wilhelmsii plant Digest Journal of Nanomaterials and Biostructures. 2011;6:1011-1017.

10. Sathishkumar M, Sneha K, Won SW, Cho CW, Kim S, Yun YS. Cinnamom zeylanicum bark extract and powder mediated green synthesis of nano-crystalline silver particles and its bactericidal activity. Colloids Surf B Biointerfaces. 2009;73:332-338.

11. Liversidge G, Cundy KC. Particle size reduction for improvement of oral bioavailability of hydrophobic drugs. Absolute oral bioavailability of nanocrystalline danazol in beagle dogs. Int $J$ Pharm. 1995;125:91-97.

12. Langer R. Biomaterials in drug delivery and tissue engineering: one laboratory's experience. Acc Chem Res. 2000;33:94-101.

13. Bonnemann H, Richards RM. Nanoscopic metal particles - synthetic methods and potential applications. Eur J Inorg Chem. 2001;10:2455-2480.

14. Song JY, Jang HK, Kim BS. Biological synthesis of gold nanoparticles using Magnolia kobus and Diopyros kaki leaf extracts. Process Biochemistry. 2009;44:1133-1138.

15. Willner IR, Baron R, Willner B. Growing metal nanoparticles by enzymes. Adv Mater. 2006;18:1109-1120.

16. Bnouham M, Ziyyat A, Mekhfi H, Tahri A, Legssyer A. Medicinal plants with potential anti-diabetic activity - a review of ten years of herbal medicine research (1990-2000). Int J Diabetes Metab. 2006;14:1-25.

17. Singh C, Sharma V, Naik PKR, Khandelwal V, Singh H. A green biogenic approach for the synthesis of gold and silver nanoparticles using Zingiber officinale. Digest Journal of Nanomaterials and Biostructures. 2011;6:535-542.

18. Vankar PS, Bajpai D. Preparation of gold nanoparticles from Mirabilis jalapa flowers. Indian J Biochem Biophys. 2010;47:157-160.

19. Mishra AN, Bhadauria S, Gaur MS, Pasricha R, Kushwah BS. Synthesis of gold nanoparticles by leaves of zero-calorie sweetener herb (Stevia rebaudiana) and their nanoscopic characterization by spectroscopy and microscopy Int J Green Nanotechnology: Physics and Chemistry. 2010;1:118-124.

20. Huang J, Li Q, Sun D, et al. Biosynthesis of silver and gold nanoparticles by novel sundried Cinnanonum camphora leaf. Nanotechnology. 2007; $18: 105104$

21. Jaiswal D, Rai PK, Watal G. Antidiabetic effect of Withania coagulans in experimental plants. Ind J Clin Biochem. 2009;24:88-93.

22. Kamel ZH, Daw I, Marzouk M. Effect of Cichorium endivia leaves on some biochemical parameters in streptozotocin-induced diabetic rats. Aus J Basic and App Sci. 2011;5:387-396.

23. Pandhare RB, Sangameswaran B, Mohite PB, Khanage SG. Antidiabetic activity of aqueous leaves extract of Sesbania sesban (L) Merr. in streptozotocin-induced diabetic rats. Avicenna Journal of Medical Biotechnology. 2011;3:37-43.

24. Das H, Chakraborty U. Anti-hyperglycemic effect of Scoparia dulcis in streptozotocin-induced diabetes. Research Journal of Pharmaceutical, Biological and Chemical Sciences. 2011;2:334-342.

25. Adiga S, Bairy KL, Meharban A, Punita IS. Hypoglycemic effect of aqueous extract of Trichosanthes dioica in normal and diabetic rats. Int J Diabetes Dev Ctries. 2010;30:38-42.

26. Sivaraj A, Devi K, Palani S, Vinoth Kumar P, Senthil Kumar B, David E. Anti-hyperglycemic and Anti-hyperlipidemic effect of combined plant extract of Cassia auriculata and Aegle marmelos in streptozotocin (STZ) induced diabetic albino rats. Int $J$ Pharmatech Research. 2009;1:1010-1016.
27. Gupta RK. Medicinal and Aromatic Plants. 1st ed. New Delhi: CBS Publishers and Distributors; 2010.

28. Nirmala A, Eliza J, Rajalakshmi M, Edel P, Daisy P. Effects of hexane extract of Cassia fistula barks on blood glucose and lipid profile in streptozotocin diabetic rats. Int J Pharmacol. 2008;4:292-296.

29. Sen AB, Shukia YN. Chemical examination of Cassia fistula. J Indian Chem Soc. 1968;45:744.

30. Rani M, Kalidhar SB. A new Anthraquinone derivative from Cassia fistula Linn. pods. Indian J Chem. 1998;373:1314-1315.

31. Bahorun T, Neergheen VS, Aruoma OI. Phytochemical constituents of Cassia fistula. Afr J Biotechnol. 2005;4:1530-1540.

32. Nune SK, Chanda N, Shukla R, et al. Green nanotechnology from tea: phytochemicals in tea as buildings block for production of biocompatible gold nanoparticles. J Mater Chem. 2009;19:2912-2920.

33. Trinder P. Determination of glucose using glucose oxidase with an alternative oxygen acceptor. Ann Clin Biochem. 1969;6:24-27.

34. Abraham EC, Huff TA, Cope ND, Wilson JB Jr, Bransome ED Jr, Huisman TH. Determination of the glycosylated hemoglobins (HB AI) with a new microcolumn procedure. Suitability of the technique for assessing the clinical management of diabetes mellitus. Diabetes. 1978;27(9):931-937.

35. Bergmeyer HU, Bowers GN Jr, Horder M, Moss DW. Provisional recommendations on IFCC methods for the measurement of catalytic concentrations of enzymes. Part 2. IFCC method for aspartate aminotransferase. Clin Chim Acta. 1976;70:F19-F42.

36. Fawcett JK, Scott JE. A rapid and precise method for the determination of urea. J Clin Pathol. 1960;13:156-159.

37. Fabiny DL, Ertinghausen G. Automated reaction-rate method for determination of serum creatinine with the CentrifiChem. Clin Chem. 1971;17(8):696-700.

38. Bartels H, Bohmer M. Eine Mikromethode zur Kreatininbestimmung [A micromethod for creatinine understanding]. Clin Chem Acta. 1971;32:81-85. German.

39. Allain CC, Poon LS, Chan CS, Richmond W, Fu PC. Enzymatic determination of total serum cholesterol. Clin Chem. 1974;20(4):470-475.

40. Reinhold JC. Standard Methods on Clinical Chemistry. Reiner M, editor. New York, NY: Academic Press; 1953.

41. Low PA, Nickander KK, Tritschler HJ. The role of oxidative stress and antioxidant treatment in experimental diabetic neuropathy. Diabetes. 1997;46 Suppl 2:38-42.

42. Junod A, Lambert AE, Orci L, Pictet R, Gonet AE, Renold AE. Studies of the diabetogenic action of streptozotocin. Proc Soc Exp Biol Med. 1967;126:201-205.

43. Raketien N, Raketien ML, Nadkarmi M. Studies on the diabetogenic action of streptozotocin. Cancer Chemother Rep. 1963;29:91-98.

44. Weiss RB. Streptozotocin: A review of its pharmacology, efficacy and toxicity. Cancer Treat Rep. 1982;66:427-438.

45. Sastry M, Ahmed A, Khan MI, Kumar R. Biosynthesis of metal nanoparticles using fungi and actinomycete. Curr Sci. 2003;85(2):162-170.

46. Fierascu RC, Ion RM, Dumitriu I. Noble metal nanoparticle synthesis in plant extracts. Optoelectronics and Advanced Materials Rapid Communications. 2010;4:1297-1300.

47. Shankar SS, Ahmad A, Pasricha R, Sastry M. Bioreduction of chloroaurate ions by geranium leaves and its endophytic fungus yields gold nanoparticles of different shapes. $J$ Mater Chem. 2003;13: 1822-1826.

48. Joshi M, Bhattacharyya A, Wazed SA. Characterization techniques for nanotechnology applications in textiles. Indian Journal of Fiber and Textile Research. 2008;33:304-317.

49. Agnieszka Sobczak-Kupiec, Dagmara Malina, Mulgorzata Zimouska, Zbigniew Wzorek. Characterization of gold nanoparticles for various medical application. Digest Journal of Nanostructures and Biomaterials. 2011;6:803-808

50. He YQ, Liu SP, Kong L, Liu ZF. A study on the sizes and concentrations of gold nanoparticles by spectra of absorption, resonance Rayleigh scattering and resonance non-linear scattering. Spectrochim Acta A Mol Biomol Spectrosc. 2005;62:2861-2866. 
51. Elavazhagan T, Arunachalam KD. Memecylon edule leaf extract mediated green synthesis of silver and gold nanoparticles. Int $J$ Nanomedicine. 2011;6:1265-1278.

52. Shirwaikar A, Rajendran K, Barik R. Effect of aqueous bark extract of Garuga pinnata Roxb. in streptozotocin-nicotinamide induced type-II diabetes mellitus. J Ethnopharmacol. 2006;107:285-290.

53. Hakim ZS, Patel BK, Goyal RK. Effects of chronic ramipril treatment in streptozotocin-induced diabetic rats. Indian J Physiol Pharmacol. 1997;41:353-360.

54. Whitton PD, Hems DA. Glycogen synthesis in perfused liver of streptozotocin-diabetic rats. Biochem J. 1975;21:150-153.

55. Naggar EMB, Bartosikova L, Zemlicka M, et al. Antidiabetic effect of Cleome drosserifolia aeria parts: Lipid peroxidation-induced oxidative stress in diabetic rats. Acta Vet Brno. 2005;74:347-352.

56. Hassan Z, Ahmed M, Yosof PM, Naidu SR, Kumar GS, Umachigi SP. Hypoglycemic effect of aqueous extract of Gynura procumbens. Pharmacology. 2008;30:50.

57. Nastran JS. Antihyperglycaemia and antilipidaemic effect of Ziziphus vulgaris $\mathrm{L}$ on streptozotocin induced diabetic adult male Wistar rats. Physiol Pharmacol. 2011;47:219-223.

58. Barathmanikanth S, Kalishwaralal K, Sriram M, et al. Anti-oxidant effect of gold nanoparticles restrains hyperglycemic conditions in diabetic mice. J Nanobiotechnology. 2010;8:16.

59. Jarald E, Joshi SB, Jain DC. Biochemical study on the hypoglycemic effects of extract and fraction of Acacia catechu wild in alloxan induced diabetic rats. Int $J$ Diabetes and Metabolism. 2009;17: 63-69.

60. Oluba OM, Onyeneke C, Ojieh GC, Idonije BO. Evaluation of the hypoglycemic effect of aqueous extract of Ganoderm lucidum on STZinduced diabetic Wistar rats. Ann Biol Res. 2010;1:41-49.

61. Kumar Rajagopal S, Manickam P, Periyasamy V, Namasivayam N. Activity of Cassia auriculata leaf extract in rats with alcoholic liver injury. J Nutr Biochem. 2003;14:452-458.

62. Li B, Wang Z, Fang JJ, Xu CY, Chen WX. Evaluation of prognostic markers in severe drug induced liver disease. World $J$ Gastroenterol. 2007;13:628-632.
63. Han KH, Hashimoto N, Shimada K, et al. Hepatoprotective effects of purple potato extract against D-galactosamine-induced liver injury in rats. Biosci Biotechnol Biochem. 2006;70:1432-1437.

64. Concepción Navarro M, Pilar Montilla M, Martín A, Jiménez J, Pilar Utrilla M. Free radical scavenger and antihepatotoxic activity of Rosmarinus tomentosus. Planta Med. 1993;59:312-314.

65. Patrick EE, Item JA, Eyong UE, Goldwin EE. The anti-diabetic efficacy of combined extracts from two conventional plants; Azadirachta indica and Vernonia amygdalina (African Biiter leaf). Am J Biochem Biotechnol. 2008;4:239-244.

66. Mahmoud MR, El-Abhar HS, Saleh S. The effect of Nigella sativa oil against the liver damage induced by Schistosoma mansoni infection in mice. J Ethnopharmacol. 2002;79:1-11.

67. Mansour HA, Newairy AA. Amelioration of impaired renal function associated with diabetes by Balanites aegyptiaca fruits in streptozotocin induced diabetic rats. J Med Res Inst. 2000;21:115-125.

68. Akah PA, Lemji JAA, Salawu OA, Okoye TC, Offiah NC. Effects of Vernonia amygdalina on biological and hematological parameters in diabetic rats. Asian Journal of Medical Sciences. 2009;1:108-113.

69. Sperling MA. Diabetes mellitus. In: Behrman RE, Kliegman RM, Arvin AM, editors. Nelson's Textbook of Pediatrics. 15th ed. Philadelphia, PA: WB Saunders; 1996:1646-1666.

70. Murali B, Upadhyaya UM, Goyal RK. Effect of chronic treatment with Enicostemma littorale in non-insulin dependent diabetic (NIDDM) rats. J Ethnopharmacol. 2002;81:199-204.

71. Patil UK, Saraf S, Dixit VK. Hypolipidemic activity of seeds of Cassia tora Linn. J Ethnopharmacol. 2004;90:249-252.

72. Alarcon AFJ, Calzada BF, Hernandez GE, Ruiz AC. Acute and chronic hypoglycaemic effect of Ibervillea sonarae root extracts - II. J Ethnopharmacol. 2005;97:447-452.

73. Daisy P, Eliza J, Ignacimuthu S. Influence of Costus speciosus (Koen) Sm. rhizome extracts on biochemical parameters in streptozotocin induced diabetic rats. J Health Sci. 2008;54: 675-681.

74. Kissane JM. Anderson's Pathology. 8th ed. Toronto, ON, Canada: Washington University School of Medicine; 1985.
International Journal of Nanomedicine

\section{Publish your work in this journal}

The International Journal of Nanomedicine is an international, peerreviewed journal focusing on the application of nanotechnology in diagnostics, therapeutics, and drug delivery systems throughout the biomedical field. This journal is indexed on PubMed Central, MedLine, CAS, SciSearch $\AA$, Current Contents ${ }^{\circledR} /$ Clinical Medicine,

\section{Dovepress}

Journal Citation Reports/Science Edition, EMBase, Scopus and the Elsevier Bibliographic databases. The manuscript management system is completely online and includes a very quick and fair peer-review system, which is all easy to use. Visit http://www.dovepress.com/ testimonials.php to read real quotes from published authors. 